\title{
Whooping Cranes in Southern Saskatchewan in 1956
}

\author{
by FRED G. BARD, Regina
}

Thanks to the interest and cooperation of farmers, sportsmen, and the public generally we know that four Whooping Cranes stayed in Southern Saskatchewan this summer. We took photographs of two at Haultain and two at Alsask for our Museum records. These pictures were taken with a telophoto lens and the birds were left undisturbed.

Pictures of the two Whooping Cranes at Alsask were taken by Gordon Duane, traveller with General Films on April 18, 1956, while he was shooting a sequence with Snow Geese. These birds were not reported till July and now they seem to have left the district. Reports of Whooping Crane should be made to the Game Branch of the Department of Natural Resources, Regina, or to the Museum; otherwise the whereabouts of these birds should be kept as quiet as possible. The public is interested in this bird and in its over enthusiasm people approach the birds too closely usually because they do not carry binoculars or want to take pictures with ordinary cameras.

Field checks in the Wood Buffalo Park by the Canadian Wildlife Service have indicated that to date (July 31,1956 ) only one pair has been found nesting. There was no evidence of young. Our late spring. may have caused conditions which have prevented the successful rearing of young Whooping Cranes in the far north and 1956, like 1954, may bring no addition to the Whooping Crane flock. It is for this reason that we are very anxious that birds remain undisturbed in Southern Saskatchewan. Alsask is only fifty miles from the site where Mr. Bradshaw saw the Whooping Crane nest in 1922. Chances of rearing young

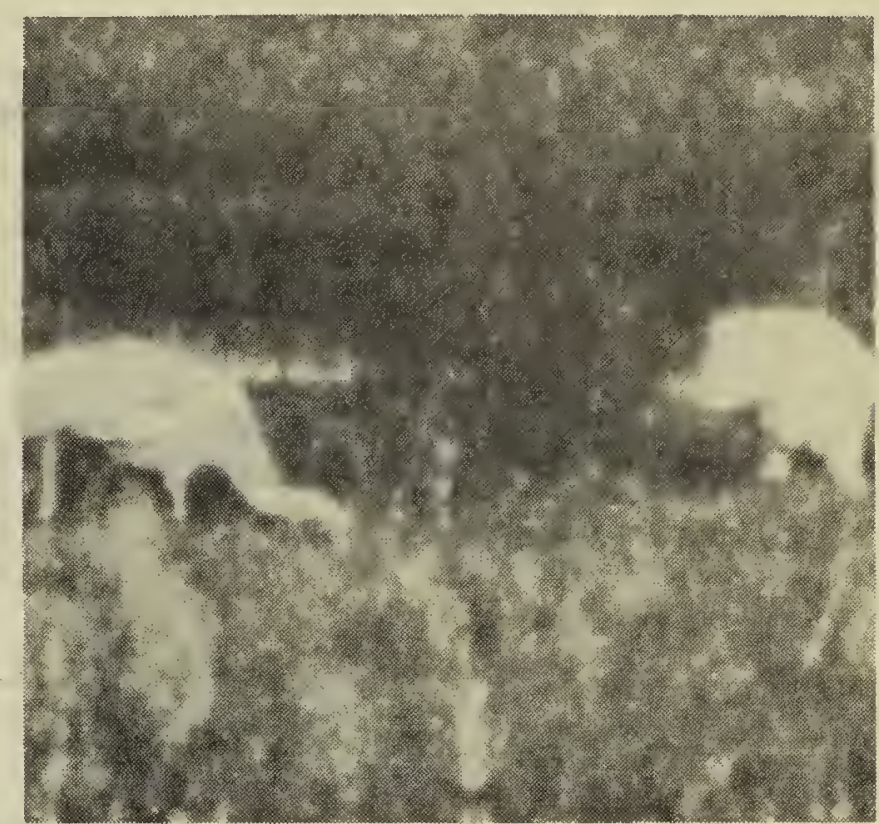

- Photo by F. G. Bard, June 25, 1956

Two Whooping Cranes at Haultain, Sask. Negative made from $16 \mathrm{~mm}$. kodachrome movie frame.

in this area should be much higher than in the far north where springs are late and often severe.

If you think you see Whooping Cranes observe them closely with binoculars. Study the flight pattern and listen to their voice. See whether or not the head is haunched back on the shoulders and whether or not the feet project beyond the length of the tail. If the birds are seen feeding, notice whether they are swimming or not. These points are important for identifying purposes. The Whooping Crane does not flock or group together in large numbers; six is the limit for a flock size.

The prairie region is the home of the Whooping Crane and we should protect them from disturbance. As we have said before they can nest earlier in our south country and the danger of their extinction is thus reduced.

\section{Black Brant Specimen}

\section{by R. W. NERO, Regina}

A Black Brant (Branta nigricans) taken some twenty years ago near Swift Current, Saskatchewan, seems to have been unrecorded and appears to constitute the first specimen for the province. Until quite recently a mounted specimen has been on display in the Swift Current Collegiate Museum where I first noticed it in September, 1955. Through the cour- 


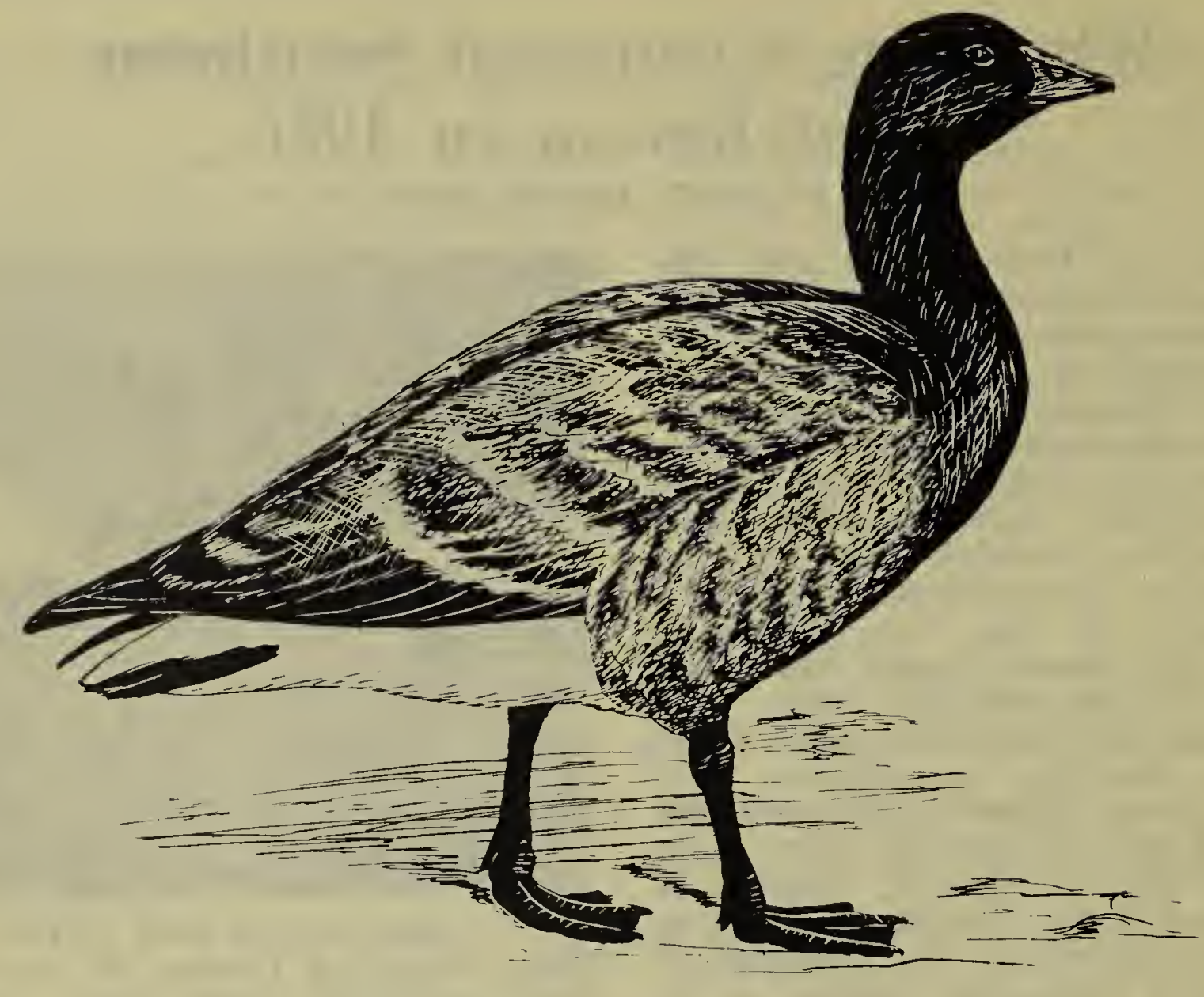

- Sketch by F. W. Lahrman

tesy of Mr. Howard E. Couch, Principal and Curator, the specimen has been placed in the Saskatchewan. Museum of Natural History.

Mr. George Warren, Swift Current taxidermist, states that he mounted the Bran:" . . . around twenty years ago ...." (Pers. Corres.). He states further, "... Mr. Lars Hendrickson was the man who shot it. I was talking to him the other day and he said it was a lone bird in a flock of Honkers and he thought he would bring it down to see what it was." Mr. Couch writes that the bird was shot "... in the district around Stewart Valley ...."

Two species of Brant are recognized on the North American continent; both are coastal species. Branta bernicla, the American Brant, is the eastern form; Branta nigricans, the Black Brant, occurs on the west coast. Their status as distinct species has recently been re-established (Handley, 1950; 26th supplement to the American Ornithologists' Union Check List of North American Birds, 1951. Auk, 68: 367). According to Taverner, the Brant is found "... breeding across the Artic coast and islands and migrating down the seacoasts. It appears inland or on fresh water only as a rare straggler. One record for Manitoba is the only authenticated one in western Canada away from the immediate vicinity of the sea." (1928: 109-110).

What is presumably the Manitoba record cited above is listed by Bent (1951:249) as an American Brant. Wood states that he examined a Black Brant shot in North Dakota, "... an immature bird ... taken at Dakota, Nelson County, October 26, 1917." (1923: 22). The Saskatchewan specimen is also an immature bird, having notched tail feathers and lacking the white collar.

\section{LITERATURE CITED}

BENT, A. C.

1951 Life histories of North American wild fowl, ducks, geese and swans.

Vol. 2. Dover Pub., N.Y. 316 pp.

HANDLEY, C. O., JR.

1950 The Brant of Prince Patrick Island, Northwest Territories. Wilson Bu1l., 62: 128-132. TAVERNER, P. A.

1928 Birds of Western Canada. Nat'l Mus. Can. Bull. No. Dv. (2nd ed. revised). WOOD, N. A.

1923 A preliminary survey of the bird life of North Dakota. Univ. Mich. Mus. Zool., Misc. Pub. No. 10. Ann Arbor, Michigan. $92 \mathrm{pp.}$ 